\title{
Scanning electron microscopy of acantholysis in pemphigus foliaceus
}

\author{
Microscopia eletrônica de varredura da acantólise no pênfigo foliáceo
}

\author{
Hiram Larangeira de Almeida Jr. ${ }^{1}$ \\ Gabriela Rossi \\ Ricardo Marques e Silva ${ }^{4}$
}

Aline Hatzenberger Leitão

Nara Moreira Rocha ${ }^{3}$

\begin{abstract}
We performed scanning electron microscopy of an inverted blister roof in a case of pemphigus foliaceus. The loss of intercellular adherence could be easily seen with low magnification. The acantholytic keratinocytes displayed an irregular and sometimes polygonal contour. Round cells, typically seen in light microscopy, were also observed. The examination of a blister roof allows ultrastructural documentation of the acantholytic changes.
\end{abstract}

Keywords: Desmosomes; Microscopy, electron, scanning transmission; Pemphigus

Resumo: Realizamos microscopia eletrônica de varredura do teto invertido de uma bolha de um caso de pênfigo foliáceo. Com pequeno aumento, a perda da adesão intercelular pôde ser vista claramente. Os queratinócitos acantolíticos demostraram um contorno irregular, algumas vezes poligonal. Células arredondadas, como vistas tipicamente na microscopia óptica, também foram observadas. O exame de um teto de bolha permite uma documentação ultraestrutural das alterações acantolíticas.

Palavras-chave: Desmossomos; Microscopia eletrônica de varredura; Pênfigo

\section{INTRODUCTION}

The pemphigus group is a well characterized subset of blistering diseases due to IgG autoantibodies against the desmosomal cadherins, desmoglein 3 and desmoglein, ${ }^{1}$ leading to acantholysis, the histological hallmark of pemphigus. ${ }^{1-3}$ Acantholysis allows differentiation with the bullous pemphigoid (BP) group, in which the whole epidermis is lost without acantholytic changes.
In order to examine these changes, we performed scanning electron microscopy of an inverted blister roof of a case of pemphigus foliaceus, which was diagnosed with light microscopy and direct immunofluorescence. The first found acantholysis in the upper epidermal layers and the second identified IgG deposition with an intercellular pattern. For comparison, the blister roof of a case of BP was also examined.

Approved by the Advisory Board and accepted for publication on 16.08.2012.

* Study conducted at the Electron Microscopy Laboratory - Federal University of Pelotas (UFPel) - Pelotas (RS), Brazil. Conflict of interest: None

Financial funding: None

Adjunct Professor, Federal University of Pelotas (UFPel) - Pelotas (RS), Brazil.

Dermatology Residency Program - Catholic University of Rio Grande do Sul (PUC-RS) - Porto Alegre (RS), Brazil.

Biologist, Empresa Brasileira de Pesquisa Agropecuária (EMBRAPA CPA-CT) - Pelotas (RS), Brazil.

Research Bursary Holder -Electron Microscopy Laboratory - Federal University of Pelotas (UFPel) - Pelotas (RS), Brazil. 


\section{RESULTS}

With low magnification the loss of intercellular adherence could be easily seen (Figure 1A). The acantholytic keratinocytes showed an irregular sometimes polygonal contour. Round cells, as typically seen in light microscopy, were also observed. These round cells had a central concavity (Figure 1B).
In the inner surface of the blister roof the adherence loss among keratinocytes could be documented, while some cells had a stretched membrane with some persistent adherence to adjacent keratinocytes (Figures 2 and 3). With very high magnification we observed the rupture of epidermal intercellular connections (Figure 4).
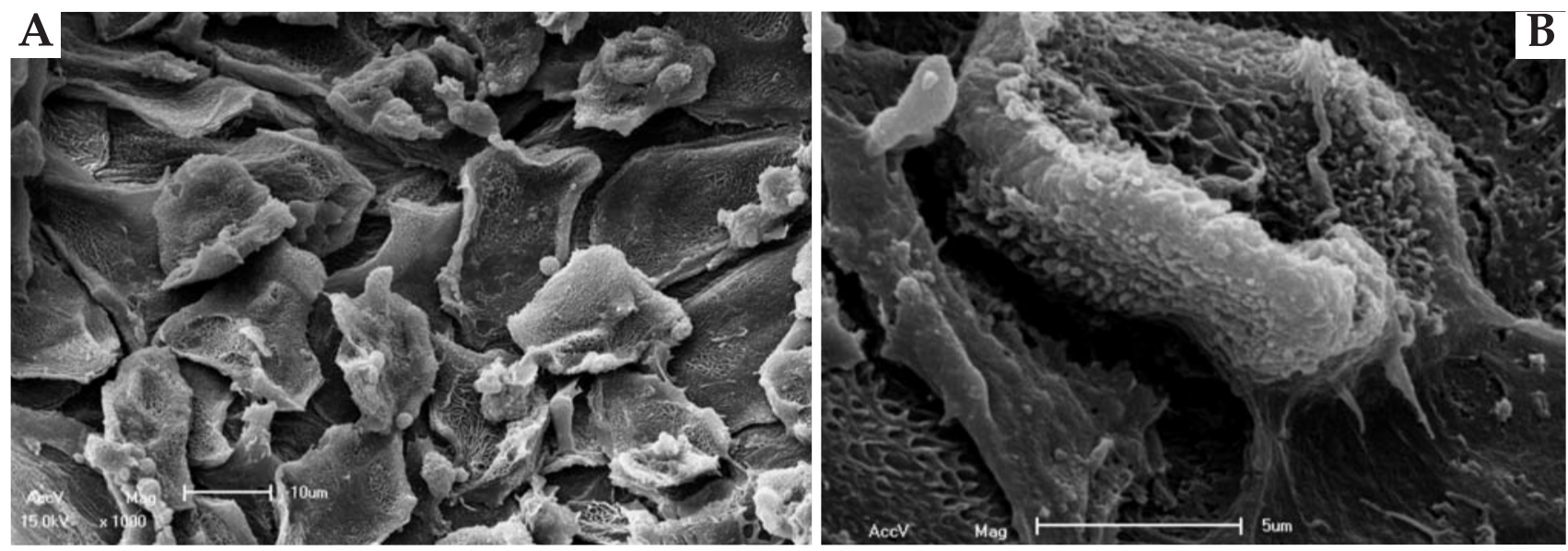

FIGURE 1: A. low magnification $(x 1.000)$ with loose keratinocytes. B. Detail of a typical round acantholytic keratinocyte (x 4.500)
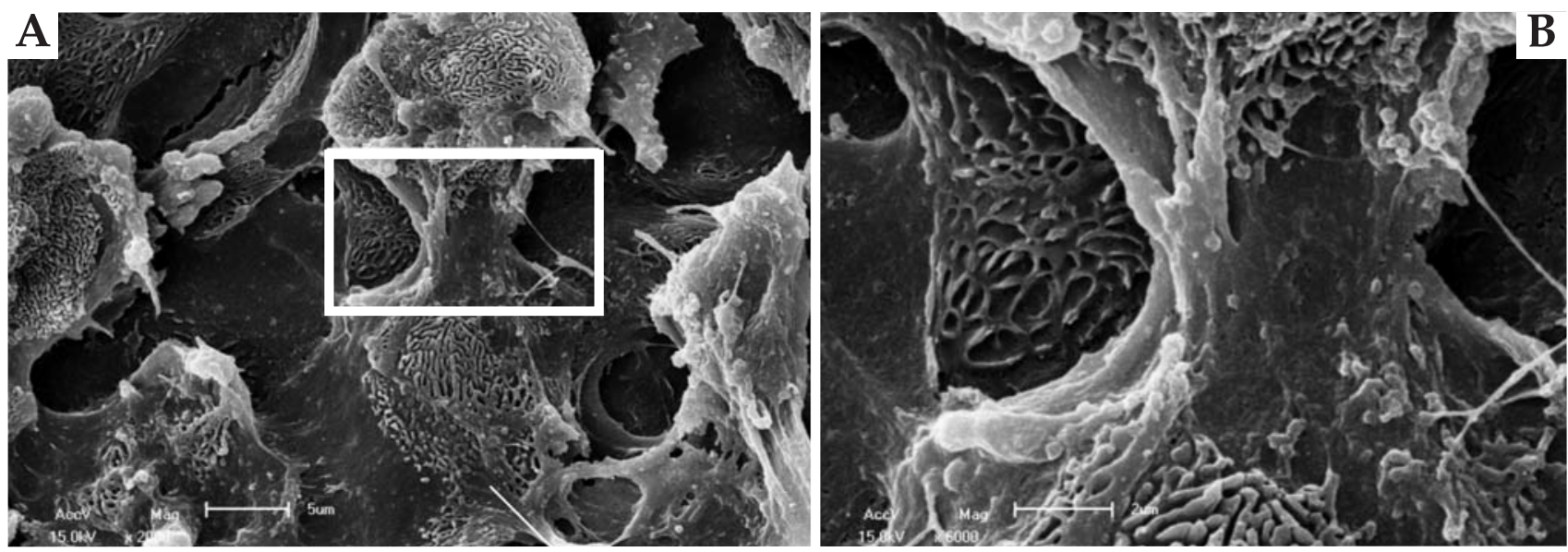

Figure 2: A. Acantholytic area (x2.000) with loose keratinocytes. B. Detail of the adhesion loss (x 6.000)
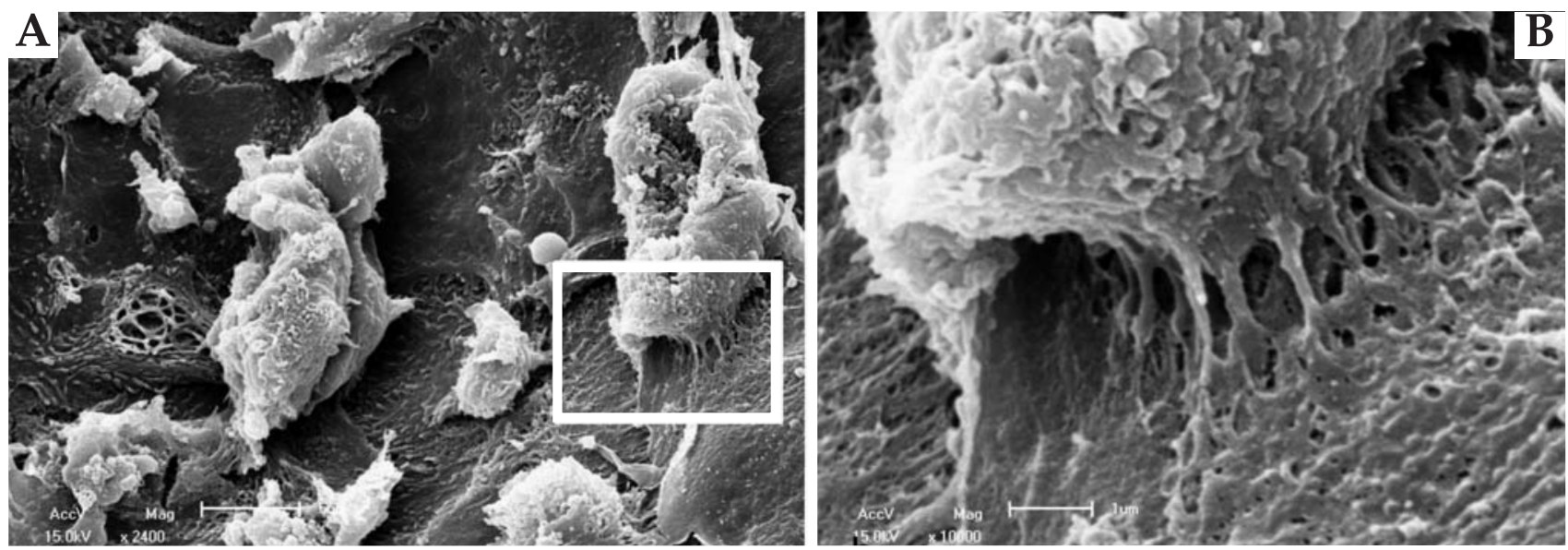

Figure 3: A. Acantholytic area with a round keratinocyte (x2.400) B. Detail of the adhesion loss $(x 10.000)$ 

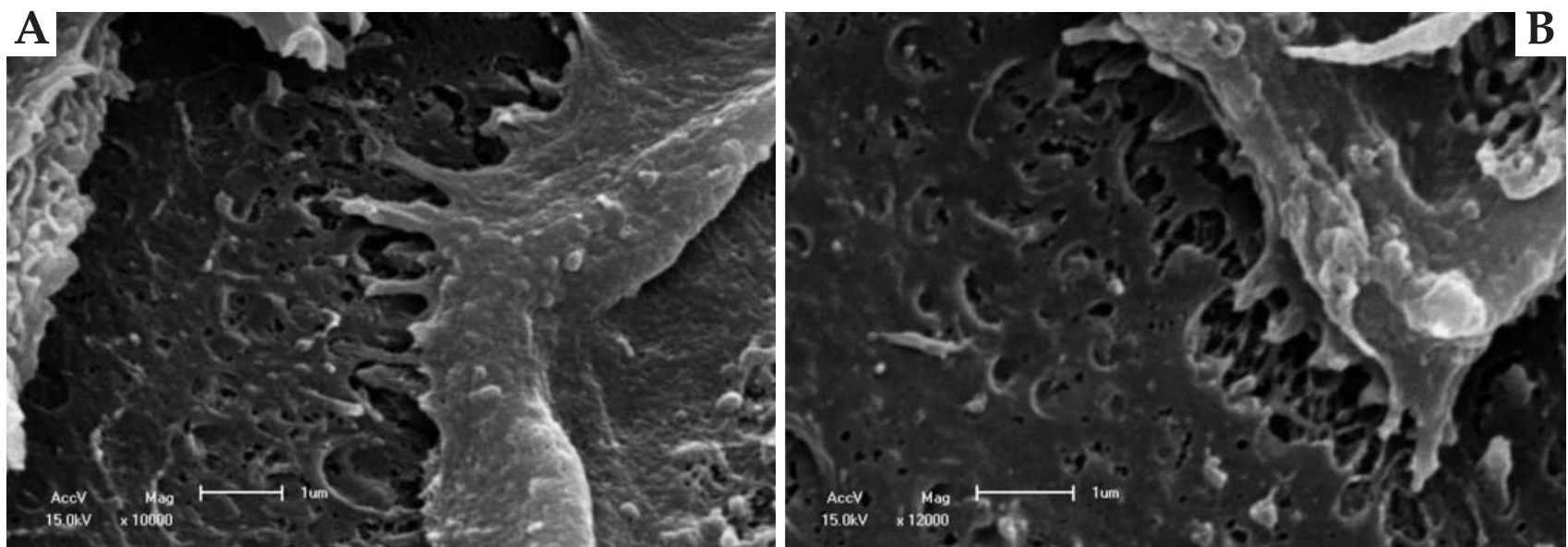

Figure 4: A - Very high magnifications (x10.000 and 12.000) B - with intercelular separation

The blister roof of a BP case shows a "solid" cell membrane, with a regular surface, without isolated cells.

\section{DISCUSSION}

Most papers with electron microscopy findings for pemphigus were published in the 1960s, when its pathogenic aspects were not completely understood..$^{4,5}$ Technological advances now provide an easier and more accurate examination with the new electron microscopes.

Two papers reporting on the use of transmission electron microscopy appeared recently in the scientific literature in English ${ }^{4,5}$ reporting the loss of adherence with widening of the intercellular spaces. Stretched desmosomes with persistence of some intercellular adherence were also found, similar to our results with SEM, which documented three-dimensionally the acantholytic phenomena observed in pemphigus foliaceus (Figures 2 and 3). ${ }^{4}$

Under SEM acantholytic keratinocytes are polygonal or round or may have an irregular border. The loss of adherence to the adjacent cells could be easily observed. These changes were not found in a blister's roof of BP examined under the same conditions.

Published SEM findings in scraps of oral mucosa in pemphigus vulgaris described also various cell shapes, as well as a central bulging or concavity in acantholytic keratinocytes, which we also found.

The examination of a blister roof, which is free of artifacts and bacterial contamination, allows a better documentation of these changes. $\square$

\section{REFERENCES}

1. Waschke J. The desmosome and pemphigus. Histochem Cell Biol. 2008;130:21-54

2. Waschke J, Bruggeman P, Baumgartner W, Zillikens D, Drenckhahn D. Pemphigus foliaceus IgG causes dissociation of desmoglein 1-containing junctions without blocking desmoglein 1 transinteraction. J Clin Invest 2005;115:3157-65

3. Aoki V, Lago F, Yamazaki MH,Santi CG, Maruta CW; The Cooperative Group on Fogo Selvagem Research. Significance of epitope spreading in the pathogenesis of pemphigus vulgaris and foliaceus. An Bras Dermatol. 2008;83:157-61.

4. Diercks GF, Pas HH, Jonkman MF. The ultrastructure of acantholysis in pemphigus vulgaris. Br J Dermatol. 2009;160:460-1.

5. Wang W, Amagai M , Ishiko A. Desmosome splitting is a primary ultrastructural change in the acantholysis of pemphigus. J Dermatol Sci. 2009;54:59-61.

6. Hietanen J. Acantholytic cells in pemphigus. A scanning and transmission electron microscopic study. Acta Odontol Scand. 1982;40:257-73.

\author{
MAILING ADDRESS: \\ Hiram Larangeira de Almeida Jr \\ Rua Gonçalves Chaves, 457 \\ 96015-560 - Pelotas - RS \\ Brazil \\ E-mail: hiramalmeidajr@hotmail.com
}

How to cite this article: Almeida HL Jr., Leitão AH, Rossi G, Rocha NM, Marques e Silva R. Scanning electron microscopy of acantholysis in pemphigus foliaceus. An Bras Dermatol. 2013;88(3):456-8. 